\title{
Nilai Perjuangan dalam Novel Arus Balik Karya Pramoedya Ananta Toer
}

\author{
Sabjan Badioo, ${ }^{\mathrm{a}, \text {, Burhan Nurgiyantoro }}{ }^{\mathrm{a}, 2}$, dan Hartono ${ }^{\mathrm{a}, 3}$ \\ aUniversitas Negeri Yogyakarta, Yogyakarta, Indonesia \\ Isabjan@abasrin.com; ${ }^{2}$ burhan@uny.ac.id; ${ }^{3}$ hartono-fbs@uny.ac.id
}

\begin{tabular}{ll}
\hline Article info & A B S T R A C T \\
\hline Article history: & This study aims to describe the struggle of the character in the \\
Revised : 05-08-2019 & novel Arus Balik. The method used is the content analysis \\
Accepted:02-10-2019 & method. Data is obtained by reading and recording techniques. \\
& Data were analyzed with qualitative descriptive analysis \\
& techniques through data comparison, categorization, data \\
& presentation, and inference. The results showed that the \\
& struggle of the character in the Arus Balik novel by Pramoedya \\
& Ananta Toer consisted of heroism (28\%), nationalism (33\%), \\
& never giving up (25\%), kinship (9\%), and selflessness (5\%). The \\
& value of the struggle for heroism consists of being wary of the \\
& enemy, defending the people, defending the truth, selflessness, \\
& daring to die, being responsible, and commanding authority. \\
& The value of nationalism consists of love for the flag itself, loyal \\
& to the leader, thinking about the safety of the country, \\
& supporting the struggle to defend the country, and participating \\
& in defending the country. The value of the unyielding struggle \\
& consists of fighting to the death and believing in your abilities. \\
Meanwhile, the value of selfless struggle consists in overcoming & not expecting respect and not expecting office.
\end{tabular}

Keywords:

heroism

kinship

nationalism

Pramoedya Ananta Toer selflessness
Penelitian ini bertujuan mendeskripsikan perjuangan tokoh dalam novel Arus Balik dengan metode analisis isi. Data diperoleh dengan teknik membaca dan mencatat. Data dianalisis dengan teknik analisis deskriptif kualitatif melalui perbandingan antardata, kategorisasi, penyajian data, dan inferensi. Hasil penelitian menunjukkan perjuangan tokoh dalam novel Arus Balik karya Pramoedya Ananta Toer terdiri atas heroisme $(28 \%)$, nasionalisme $(33 \%)$, pantang menyerah (25\%), kekeluargaan (9\%), dan tanpa pamrih (5\%). Nilai perjuangan heroisme terdiri atas waspada terhadap musuh, membela rakyat, membela kebenaran, tidak mementingkan diri sendiri, berani mati, bertanggung jawab, serta berwibawa memimpin pasukan. Nilai nasionalisme terdiri atas cinta pada bendera sendiri, setia pada pemimpin, memikirkan keselamatan negara, mendukung perjuangan bela negara, serta ikut serta membela negara. Nilai perjuangan pantang menyerah terdiri atas melawan sampai mati dan percaya kepada kemampuan sendiri. Sementara itu, nilai perjuangan tanpa pamrih terdiri atas tidak mengharapkan penghormatan dan tidak mengharapkan jabatan.

Copyright @ 2019 Institut Agama Islam Negeri Syekh Nurjati Cirebon. 


\section{Indonesian Language Education and Literature \\ e-ISSN: 2502-2261 \\ http://www.syekhnurjati.ac.id/jurnal/index.php/jeill/ \\ Vol. 5, No. 1, Desember 2019, $33-46$}

\section{PENDAHULUAN}

Novel sejarah, sesuai dengan namanya, menghadirkan berbagai informasi sejarah, dalam berbagai unsurnya. Informasi sejarah yang dihadirkan harus cukup signifikan agar novel yang mengangkatnya dapat dikategorikan sebagai novel sejarah. Informasi sejarah tersebut di antaranya berupa keadaan masyarakat yang melahirkan karya tersebut (Nugraha, Wardhani, \& Rakhmawati, 2019). Arus Balik adalah novel yang mengangkat latar awal Abad XVI. Oleh karena itu, berbagai berbagai informasi yang dihadirkan berhubungan dan terikat dengan fakta-fakta atau konteks sejarah pada masa itu (Kurniawan, 2017).

Awal Abad XVI identik dengan beberapa peristiwa besar yang terjadi di Nusantara, mulai memudarnya kekuatan kerajaan, masuknya Portugis, hingga berbagai peristiwa penting yang terjadi setelah Portugis masuk ke Nusantara. Arus Balik banyak bercerita tentang usaha-usaha mempertahankan kelangsungan sebuah kerajaan, mempertahankan eksistensi kerajaan di tengah pengaruh kuat Portugis dan tekanan kerajaan lain, termasuk di dalamnya berbagai informasi tentang ekonomi, politik, budaya, agama, hingga kemaritiman (Kumaidi, 2017).

Pramoedya Ananta Toer dipandang cukup intens menghadirkan unsur kesejarahan dan nilai perjuangan dalam karyanya, sebagian besar menampilkan kolonialisme, nasionalisme, dan berbagai konflik yang ditimbulkannya (Gunawan, Bandarsyah, \& Fauzi, 2019). Di antara karyanya yang sarat sejarah adalah tetralogi Bumi Manusia, Panggil Aku Kartini Saja, Gadis Pantai, Arok Dedes, Hoa Kiau di Indonesia, dan Arus Balik. Kisah dalam novel Arus Balik didukung data empiris, historis, dan logis. Selain perihal kedatangan Portugis, Pramoedya juga mengangkat islamisasi Jawa dengan ideologi politik, politik, agama, budaya, sosial, ekonomi yang melibatkan para pedagang Arab yang membawa Islam, pedagang dari India membawa Hindu-Budha, pedagang Cina membawa Konfusius, dan pedagang Portugis membawa agama Katolik (Sudikan \& Tjahjono, 2018).

Usaha-usaha membendung dan mempertahankan diri, komunitas hingga negara tersebut tidak jarang menghadirkan konflik, baik batin maupun fisik, mulai pribadi hingga komunal. Dari berbagai perisitiwa ini lahirlah para pahlawan, yaitu orang-orang yang dianggap mewakili kepentingan banyak orang pada sebuah komunitas dalam menghadirkan nilai-nilai perjuangan (Chaerulsyah, 2014). 


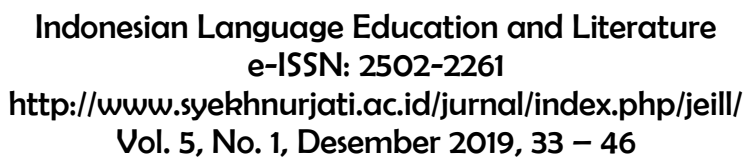

\section{METODE}

Sumber data penelitian ini adalah novel Arus Balik karya Pramudya Ananta Toer. Novel tersebut diterbitkan Hasta Mitra tahun 1995. Teknik pengumpulan data yang digunakan adalah baca-catat. Dalam teknik pengumpulan data, juga dilakukan reduksi. Langkah ini diharapkan untuk mengurangi data yang tidak relevan. Keseluruhan data yang ditemukan selama kegiatan penelitian diklasifikasikan berdasarkan butir-butir kepahlawanan yang telah ditentukan. Instrumen yang digunakan dalam penelitian ini adalah human instrumen.

Validitas data yang digunakan adalah validitas semantik, peneliti melihat seberapa jauh data berupa kepahlawanan yang dapat dimaknai sesuai konteksnya. Reliabilitas yang digunakan adalah reliabilitas intrarater dan reliabilitas interrater. Reliabilitas intrarater dilakukan dengan pembacaan berulang untuk memperoleh data tetap sampai reliabel. Reliabilitas interrater dilakukan dengan mendiskusikan hasil pengamatan dengan pengamat lain. Teknik analisis data dalam penelitian ini adalah analisis deskriptif kualitatif.

\section{HASIL DAN PEMBAHASAN}

Perjuangan dalam novel Arus Balik terdiri atas heroisme (28\%), nasionalisme (33\%), pantang menyerah (25\%), kekeluargaan (9\%), dan tanpa pamrih $(5 \%)$. Heroisme terdiri atas waspada terhadap musuh, membela rakyat, membela kebenaran, tidak memenntingkan diri sendiri, berani mati, bertanggung jawab, serta berwibawa memimpin pasukan. Nasionalisme terdiri atas cinta pada bendera sendiri, setia pada pemimpin, memikirkan keselamatan negara, mendukung perjuangan bela negara, serta ikut serta membela negara. Pantang menyerah terdiri atas melawan sampai mati dan percaya kepada kemampuan sendiri. Sementara itu, sikap tanpa pamrih terdiri atasi tidak mengharapkan penghormatan dan tidak mengharapkan jabatan.

\section{Heroisme}

Heroisme merupakan keberanian membela kebenaran dan keadilan. Secara historis, heroisme identik dengan pelayanan militer (Franco \& Zimbardo, 2007). Pada praktiknya pemikiran atau tindakan herois tidak hanya menjadi peluang bagi militer, melainkan telah juga menjadi peluang bagi seluruh elemen masyarakat (Primasari, 2014). Pemikiran dan atau tindakan bernuansa herois dalam novel 
Arus Balik meliputi delapan hal, yaitu waspada terhadap musuh, membela rakyat lemah, membela kebenaran, tidak mementingkan diri sendiri, berani mati, bertanggung jawab, dan berwibawa dalam memimpin pasukan. Sikap waspada terhadap musuh terlihat pada kutipan berikut.

"Silahkan mengaso. Sebentar lagi Tuban akan nampak."

"Lihat yang baik, barangkali ada iring-iringan perompak."

"Tak pernah ada perompak berani mendekati kapal sahaya."

"Lihat yang baik," gertak Patragading. Tangannya membetulkan kain penutup dadanya. (hal. 2)

Patragading adalah anak Adipati Tuban, Arya Teja Tumenggung Wilwatikta. Peristiwa pada kutipan tersebut terjadi saat Patragading menempuh perjalanan ke Tuban kota, melaporkan perebutan Jepara oleh Adipati Unus, Putra Mahkota Kerajaan Demak. Walaupun nakhoda dan pengintai mengatakan keadaan aman, Patragading tidak mau percaya begitu saja apalagi langsung melonggarkan kewaspadaannya terhadap musuh.

Tentang Adipati Unus sendiri ada beberapa pendapat, Tomé Pires menyebutkan bahwa penguasa Demak kedua adalah Pate Rodim Sr., orang Portugis menyebutnya dengan nama Pate Unus, dan cerita tradisi Jawa Barat menyebutnya $\mathrm{Cu}-\mathrm{Cu}$ atau Arya Sumansang dan penulis Portugis, Rouffaer, menyebutkan Pangeran Sabrang Lor ('pangeran seberang utara', menunjukkan tempat tinggalnya; berdasarkan legenda Mataram) yang terdapat dalam cerita tradisi adalah Pate Unus (Graaf \& Pigeaud, 2003).

Sebagai tokoh utama dan tokoh protagonis, tindakan herois juga ditunjukkan oleh Wiranggaleng. Tindakan herois Wiranggaleng berupa pembelaannya kepada rakyat lemah. Hal tersebut terlihat pada kutipan berikut.

Begitu selesai beseru-seru ia telah berada dalam kepungan beberapa belas orang Portugis.

"Syahbandar-muda bicara di bandarnya," ia berseru dengan nada memperingatkan. "Hentikan perbuatan kalian. Kembalikan barang-barang yang kalian rampas!" (hal. 225)

Peristiwa itu terjadi saat Portugis berkunjung ke Tuban. Saat pimpinannya menghadap adipati, beberapa orang Portugis membuat keonaran. Galeng atau 
Wiranggaleng tidak tega melihat rakyat lemah disakiti. Dia melakukan pembelaan walaupun harus mempertaruhkan nyawanya. Dengan kekuatan dan ketangkasan Galeng, orang-orang Portugis akhirnya dapat dilumpuhkan.

Tindakan herois dalam wujud membela kebenaran diwujudkan oleh Rama Cluring, seorang pemuka agama yang ceramahnya sering didengarkan Galeng dan istrinya, Idayu. Cluring mengetahui bahwa menentang adipati akan menyebabkan dirinya diburu tentara Tuban. Bahkan, bisa jadi, bukan hanya dirinya ayang akan diburu, melainkan seluruh warga yang mengikuti pengajiannya dapat ikut ditumpas. Kendati mengetahui risiko tersebut, Cluring tidak takut atau gentar. Baginya, kebenaran lebih utama dibandingkan rasa takut menghadapi pasukan Tuban. Cluring punya pandangan jauh ke depan. Dia beranggapan, dengan tegaknya kebenaran, rakyat Awis Kerambil bisa lebih maju dari saat itu.

Pada peristiwa lain, Idayu dan Galeng menunjukkan sikap kepahlawanannya dengan cara tidak mementingkan diri sendiri.

"Rama, Rama," panggil Idayu, "jangan kutuki kami, jangan sumpahi kami, jangan tulah kami, demi Hyang Widhi, demi desa Rama sendiri, demi kesejahteraan kami semua, ya Rama, Rama...." (hal. 17)

Peristiwa tersebut terjadi setelah Rama Cluring diracun oleh Kepala Desa Awis Kerambil. Perbuatan kepala desa itu dipandang berakibat buruk bagi Desa Awis Kerambil, terutama jika Rama Cluring mengeluarkan kutukannya. Warga Desa Awis Kermbil percaya, kutupan seorang pemuka agama akan segera terjadi.

Mendapat kesempatan mengurus langsung Rama Cluring, tidak dijadikan sebagai kesempatan bagi Idayu dan Galeng untuk meminta ampun dan mencari keselamatan bagi mereka sendiri. Keduanya lebih memilih memintakan ampun bagi semua warga yang ada di desanya.

Tindakan herois berani mati ditunjukkan Wiranggaleng dan Bupati Tuban Arya Teja Tumenggung Wilwatikta. Wilwatikta merupakan nama lain dari Majapahit (Wahyudi, 2013). Arya Teja memerintah Kekaisaran Majapahit setelah periode penurunan dan jatuh. Dia berkecil hati, jadi lebih fokus pada wilayahnya sendiri, yaitu tanah Tuban (Sudikan \& Tjahjono, 2018). Sikap berani mati Wiranggaleng dapat dilihat ketika dirinya berhadapan dengan penguasa Tuban sebagaimana terlihat pada kutipan berikut. 
...Ia tertawakan dirinya sendiri. Segala macam hukuman takkan berarti. Kalau soalnya hanya mati, berapa kali saja ia telah hadapi maut di panggung gulat!.... (hal. 88)

Sementara itu, sikap berani mati Arya Teja ditunjukkan atas prinsipnya untuk mengutamakan keselamatan. Ketika harus menemui kematian, sebagai seorang kesatria dirinya memilih kematian melalui pertarungan.

Terhadap keamanan jiwa pribadi ia tak pernah punya waswas. Leluhurnya, dari penguasa yang satu pada penguasa yang lain telah membangunkan sikap batin satria: hanya ada satu macam maut dengan tiga nilai, tidak kurang dan tidak lebih. Nilai pertama dan terpuji adalah maut karena lanjut usia, nilai kedua yang patut adalah karena kehormatan sebagai satria, di medan perang dan di mana saja. Nilai ketiga yang dianggapnya hina adalah karena hukuman dan tidak dengan keris. Dan seorang satria hanya boleh mengambil dua nilai yang sebelum yang terakhir. Setiap saat ia bersedia mati baik karena usia mau pun karena kehormatan. Ia tak pernah punya keraguan. (hal. 355)

Bagi seorang kesatria, keselamatan sampai akhir usia merupakan hal yang utama. Jika harus mati karena faktor lain, mereka akan mencari kematian yang dianggap paling jantan, yaitu dengan pertarungan. Jika mengalami kekalahan atau mendapatkan hukuman, kematian yang mereka banggakan adalah kematian dengan keris, menempati urutan kedua dengan pedang, dan merupakan kehinaan jika sampai meninggal dengan faktor lain, misalnya dengan cambuk. Begitu juga jika yang melakukan penghukuman bukan orang yang sederajat dengannya (di bawahnya). Mereka akan lebih senang jika si penghukum berkedudukan sama atau di atasnya, misalnya sama-sama pangeran, sama-sama raja, atau punggawa dihukum oleh raja.

Rasa tanggung jawab sebagai wujud dari heroisme ditunjukkan oleh Wiranggaleng yang dengan setia menyelesaikan tugas kenegaraan yang diembannya. Sementara itu, sikap berwibawa di antaranya ditunjukkan Wiranggaleng saat memimpin pasukan. Kewibawaan Wiranggaleng ini mampu meningkatkan semangat anak buahnya. 
Melihat Ki Aji kembali pada meja-lipatnya hendak memasukkan surat itu ke dalam kitab, ia melompat. Ditangkapnya tangan itu dan dirampasnya kembali surat itu. Bapa Kiai memekik. Wiranggaleng menguguh mulutnya.... (hal. 267)

Kutipan tersebut menunjukkan tanggung jawab Galeng dalam menjaga keselamatan lontar yang harus diterjemahkannya. Lontar tersebut berasal dari Sunan Rajeg yang ditujukan ke Syahbandar Tuban. Saat di medan perang, tanggung jawab Wiranggaleng juga terlihat. Dia tidak hanya memerintahkan anak buahnya untuk bertempur. Wiranggaleng bahkan bertempur di garis depan sambil memberi komando. Hal inilah salah satu penyebab tentara Tuban sangat bangga dan menghormatinya.

Selain rasa tanggung jawab, faktor penentu keberhasilan perjuangan tentara Tuban melawan pemberontakan Sunan Rajeg dan melawan Portugis yang sempat menguasai Tuban, adalah kewibawaan Wiranggaleng dalam memimpin pasukan.

Dan Senapati Tuban, Wiranggaleng, ternyata tak pernah dapat ditemuinya. Belum ada orang yang dapat bercerita bertemu, apalagi bicara dengannya. Namun demikian kewibawaannya dapat dirasakan oleh setiap prajurit. Perselisihan antara pemimpin-pemimpin pasukan lenyap seperti dihembus angin. Setiap orang menunggu dengan taat akan datangnya perintahnya. Dan dalam waktu pendek ketidakacuan para petani di pendalaman dapat dilawannya. (hal. 710)

Pada kutipan tersebut terlihat begitu berwibawanya Wiranggaleng. Hanya dengan mendengar kedatangannya saja, terjadi perubahan luar biasa. Padahal, sebelum kedatangannya dari Malaka, terjadi perselisihan antara pemimpin pasukan Tuban. Selain itu, petani-petani-rakyat Tuban pada umumnya-tidak mau ikut serta dalam perlawanan melawan Portugis. Kutipan di atas juga menunjukkan begitu pentingnya arti seorang pemimpin bagi masyarakat Tuban.

Pemikiran dan tindakan yang dilakukan oleh Patragading, Wiranggaleng, Idayu, Rama Cluring, dan Arya Teja Tumenggung Wilwatikta bukanlah sesuatu yang ekslusif, melainkan dapat dilakukan oleh siapa pun yang berada dan terkait dengan peristiwa berpeluang melakukan hal yang sama. Inilah yang menjadikan tindakan Patragading, Wiranggaleng, dan Rama Cluring menjadi istimewa. 


\section{Nasionalisme}

Nasionalisme dapat dimaknai sebagai paham kebangsaan atau ideologi yang menekankan kepada para pengikutnya untuk mencintai bangsanya (Sulistiyono, 2018). Secara praktis, nasionalisme dapat diartikan sebagai rasa cinta tanah air dan bangsa (Chaerulsyah, 2014) atau kesadaran keanggotaan dalam suatu bangsa yang secara potensial atau aktual bersama-sama mencapai, mempertahankan, dan mengabadikan identitas, integritas, kemakmuran, dan kekuatan bangsa (Badan Pengembangan dan Pembinaan Bahasa Kemdikbud RI, 2016). Kecintaan terhadap tanah air terwujud dalam bentuk cinta pada bendera sendiri, setia kepada penguasa, memikirkan keselamatan negara, mendukung perjuangan membela negara, dan ikut serta membela negara. Sikap cinta pada bendera sendiri terlihat pada kutipan berikut.

"Kupu-tarung lebih bagus daripada merah-putih," seseorang memberikan tanggapan. (hal. 8)

Kupu-tarung adalah bendera Jepara, sedang merah-putih adalah bendera Tuban yang diwarisi dari Majapahit. Bendera Jepara juga berwarna merah putih, setelah direbut oleh Adipati Unus, berganti kupu-tarung.

Nasionalisme juga dapat wujudkan dalam bentuk kesetiaan kepada bangsa dan negara (Firmansyah, 2015), dalam hal ini kesetiaan kepada penguasa atau pemerintah yang sah. Penguasa (raja) di sini adalah Adipati Tuban. Pada pemerintahan sistem kerajaan, raja sama artinya dengan negara. Walaupun negara diserang dan dikuasai musuh, jika raja masih selamat, masih ada kemungkinan untuk merebut kembali negaranya.

“Ampun, Gusti Adipati Tuban sesembahan patik. Patik, kepala pasukan pengawal Gusti Adipati tiada rela Tuban dijamah oleh musuh dari mana pun datangnya, siapa pun orangnya, apa pun dalih dan kapan pun makarnya. Seluruh pasukan pengawal adalah kulit Gusti Adipati. Barang siapa menyentuh kulit itu, dia akan robek di bawah injakan pasukan pengawal, karena Braja yang akan menjawab."

"Kesetiaanmu adalah kesetiaan lama dari perwira Majapahit.... (hal. 322)

Peristiwa di atas terjadi pada sebuah penghadapan yang membicarakan ancaman pemberontakan Sunan Rajeg atau Iskak Indrajit, mantan Syahbandar 
Tuban yang tidak setuju dengan pemecatan dan penggantiannya. Selain itu, nasionalisme berwujud tindakan memikirkan keselamatan negara.

...”Bergabung dengan negeri-negeri lain, Gusti, dengan semua kerajaan Islam, bersama-sama menghancurkan Peranggi dan Ispanya. Menurut patik, itulah satu-satunya jalan menyelamatkan Tuban .... (hal. 57)

Pada kutipan itu terlihat, seorang saudagar yang mengkhawatirkan tindakan Portugis yang ingin menguasai bandar-bandar. Jika hal ini terjadi, Nusantara menjadi terancam, demikian pula dengan kelangsungan perkembangan Islam. Pemikiran saudagar ini merupakan hal yang baru bagi penduduk nusantara. Nasionalisme yang hadir selama ini bersifat lokal, bahkan hanya ditujukan pada individu (raja atau penguasa). Saudagar tersebut sudah memikirkan sesuatu yang dinamakan keamanan bersama, keamanan wilayah, atau keamanan kawasan, sebuah konsep yang menempatkan persatuan dan kesatuan atas berbagai perbedaan yang ada atas dasar persamaan nasib (Bakar, Noor, \& Widodo, 2018).

\section{Pantang Menyerah}

Pantang menyerah dapat diartikan sebagai sikap atau tekad pantang mundur dalam menghadapi kesulitan atau hambatan selama perjuangan. Sikap ini juga terlihat dengan sikap seseorang yang selalu mencari alternatif pemecahan terbaik terhadap permasalahan yang dihadapi. Substansi pantang menyerah terdiri atas dua hal, yaitu melawan sampai mati dan percaya pada kemampuan sendiri.

Seseorang yang berjuang dengan sepenuh jiwa dan raganya, tidak akan berhenti berjuang kecuali karena dua hal, yaitu menang atau mati, tidak ada istilah menyerah. Hal seperti inilah yang dilakukan Adipati Jepara saat diserang oleh Adipati Unus sebagaimana tergambar pada kutipan berikut.

"Ampuni patik, membangunkan Paduka pada malam buta begini. Kabar duka, Paduka. Balatentara Demak di bawah Adipati Kudus memasuki Jepara tanpa diduga-duga, menyalahi aturan perang."

"Allah Dewa Batara!” sahut Sang Patih. "Itu bukan aturan raja-raja! Itu aturan brandal!"

"Balatentara Tuban tak sempat dikerahkan, Paduka."

"Bagaimana Bupati Jepara?"

"Tewas enggan menyerah Paduka," Patragading mengangkat sembah.... (hal. 18-19) 
Sikap pantang menyerah sampai mati yang ditunjukkan oleh Adipati Jepara tersebut terungkap melalui laporan Patragading, salah satu anak Adipati Tuban yang bertugas. Varian yang kedua yaitu percaya pada kemampuan sendiri terlihat pada pernyataan Adipati Unus saat menyerang Portugis di Malaka.

Unus meneruskan perintahnya: "Hari ini si kafir harus angkat kaki dari bumi Malaka. Hari ini! Insya Allah. Kalau Peranggi telah terusir, mulai sekarang seluruh laut bagian selatan, seluruh perairan Nusantara akan kembali jadi milik kita bersama lagi." (hal. 198)

Adipati Unus mengalami kekalahan dalam pertempuran melawan Portugis di Malaka. Permasalahannya bukan kalah dan menang, melainkan keberaniannya dan sikap percaya diri yang dimilikinya. Dia yakin bahwa tentaranya dapat mengalahkan Portugis yang dianggap "manusia super" yang tak terkalahkan, terutama dalam hal persenjataan, meriam dan musket (senjata api).

Peristiwa ini terjadi pada tahun 1513 Masehi diawali oleh penyerangan Katir yang berasal dari Jepara. Karena mengalami kekalahan, dia meminta bantuan pasukan kepada Jepara. Jepara mengirimkan 10.000 prajurit dengan 100 buah kapal. Armada yang melakukan penyerangan tanggal 1 Januari 1513 ini mengalami kekalahan, hanya tujuh kapal yang bisa kembali ke Jepara (Poesponegoro \& Notosusanto, 1984).

\section{Kekeluargaan}

Kekeluargaan dapat diartikan sebagai pemikiran yang mengacu pada prinsip keluarga. Hanya saja prinsip kekeluargaan ini tidak harus berlaku atau dilakukan pada satu kelompok sedarah. Kekeluargaan lebih mengarah pada cara menghadapi sesuatu dengan memandang "kawan ataupun lawan" seperti keluarga sehingga permasalahan yang ada akan diselesaikan seperti persoalan antarmanusia yang memiliki hubungan darah. Kekeluargaan terdiri atas empat varian, yaitu menolong orang lain, berbahagia atas kebahagiaan orang lain, mendamaikan orang yang berselisih, dan bermusyawarah dalam mengambil keputusan. Wujud varian menolong orang lain terlihat pada kutipan berikut.

"Kang, aku kuatir," Idayu berbisik dan memandangi suaminya dengan mata sayu. "Aku takut, Kang. Di desa aku tak pernah takut seperti ini."

"Kalau diperkenankan, kami sedia ikut menjaga, Wira," seseorang di antara para perubung mengusulkan. (hal. 135) 
Rakyat Tuban yang mengetahui bahwa Wiranggaleng akan berangkat menyelidiki perkembangan Demak dan persiapannya menyerang Malaka, menunjukkan rasa kekeluargaannya dengan sikap bersedia menjaga Idayu, istri Wiranggaleng sekaligus penari pujaan Tuban yang sangat mereka hormati. Sikap seperti ini terlihat pula pada peristiwa Idayu diculik Sunan Rajeg. Seluruh Tuban gempar dan tidak seorang pun akan memaafkan jika sampai Idayu cidera. Sikap kekeluargaan juga ditunjukkan rakyat Tuban yang mendengar Gelar, anak Idayu, sedang bertempur dan sedang disergap pasukan Demak. Masyarakat mendoakan keselamatannya.

Perjuangan Idayu untuk mendapatkan cintanya harus melalui ancaman maut. Penolakannya atas keinginan adipati mendekatkannya ke ujung keris. Namun, faktor lain menunjukkan kekuatannya. Seorang raja feodal seperti Adipati Tuban terpaksa harus mengalah setelah melihat dukungan rakyatnya atas Idayu dan Galeng, bahkan timbul kesadaran untuk turut berbahagia atas perjuangan, tekad, dan keberhasilan Idayu dan Galeng meraih cinta.

Mendamaikan orang yang berselisih merupakan varian lain yang menunjukkan indikasi kekeluargaaan. Hal tersebut terlihat pada tindakan Kala Cuwil pada kutipan berikut.

Kala Cuwil mendengus menahan kegusaran Banteng Wareng. Ia memang terkenal sebagai juru damai yang tidak pernah berpihak, maka orang mendengarkan setiap katanya: "Ikan besar umpan pun besar." (hal. 361)

Sementara itu, sikap bermusyawarah dalam mengambil keputusan ditunjukkan Wiranggaleng sebagai panglima perang. Kendati dirinya berhak memutuskan, Galeng tetap meminta pendapat atau persetujuan berbagai pihak. Sikap seperti inilah yang menjadi salah satu penyebab Wiranggaleng selalu dihormati.

Kekeluargaan merupakan nilai komunal tempat bersemayamnya solidaritas dan cinta kasih antarmanusia (Rivaie, 2011:94). Nilai ini pada dasarnya bisa hadir pada diri setiap manusia. Hanya saja, tidak setiap manusia mengekspresikannya dengan baik. 


\section{Tanpa Pamrih}

Tanpa pamrih ditandai dengan perjuangan yang dilakukan semata-mata demi tujuan perjuangan, tanpa disertai oleh kepentingan personal, semata ingin menolong. Dengan kata lain, pejuang berjuang dengan tanpa mengharapkan imbalan apapun dan tanpa mengharapkan balas budi dari siapapun. Varian sikap tanpa pamrih yang ditemukan adalah tidak mengharapkan penghormatan dan tidak mengharapkan jabatan. Tidak mengharapkan penghormatan ditunjukkan oleh Rama Cluring pada kutipan berikut.

Tak ada guna cinta dan hormat," Rama meliuk-liuk dan meringis kesakitan. "Kalau kata-kataku bisa hidup dalam hati mereka, cukup sudah." Ia muntah. (hal. 17)

Sebagai tokoh agama, Rama Cluring konsisten dengan perjuangkannya, murni untuk kemanusiaan. Dia menunjukkan bahwa tidak ada unsur pribadi dalam perjuangannya. Tindakan Rama Cluring ini senada dengan apa yang dilakukan Patih Tuban. Dia tahu bahwa dirinya punya kesempatan untuk menguasai Tuban. Dia juga tahu bahwa adipati bukanlah tipe penguasa yang baik. Namun, dia adalah bawahannya yang sudah berjanji untuk mengabdi kepada adipati. Karena itu, dia akan mengabdikan seluruh hidupnya untuk adipati, walau mendapati banyak kekecewaan.

Idayu, isteri Galeng, juga menunjukkan sikap tanpa pamrihnya dengan tidak mengharapkan jabatan. Karena itu, tidak heran kalau beberapa tahun kemudian, pada akhir cerita, mereka ditemukan sebagai sepasang petani dengan sisa-sisa ketegapan dan kecantikan berada di tengah hutan rimba.

\section{SIMPULAN}

Perjuangan dalam novel Arus Balik terdiri atas heroisme, nasionalisme, pantang menyerah, kekeluargaan, dan tanpa pamrih. Berdasarkan uraian tersebut, wujud nilai perjuangan dalam novel Arus Balik karya Pramoedya Ananta Toer merupakan wujud nilai atau karakter yang patut diteladankan serta umumnya dapat dimiliki oleh siapa saja. Nilai-nilai perjuangan ini bukan sesuatu yang ekslusif, dalam arti hanya dapat dilakukan oleh orang tertntu. Perwujudan nilai- 
nilai tersebut dapat berupa banyak hal serta dapat dilakukan oleh siapa pun dalam kehidupan nyata.

\section{DAFTAR PUSTAKA}

Badan Pengembangan dan Pembinaan Bahasa Kemdikbud RI. (2016). KBBI Daring, https://kbbi.kemdikbud.go.id/entri/nasionalisme.

Bakar, K.A.A, Noor, I.H.M., \&Widodo. (2018). Penumbuhan nilai karakter nasionalis pada sekolah dasar di Kabupaten Jayapura Papua. Cakrawala Pendidikan, 27(1), 42-56.

Chaerulsyah, E.M. (2014). Persepsi siswa tentang keteladanan pahlawan nasional untuk meningkatkan semangat kebangsaan. Indonesian Journal of History education, 3(1), 1-5.

Firmansyah, W. \& Kumalasari, D. (2015). Penanaman nilai-nilai nasionalisme melalui pembelajaran sejarah di SMA Kebangsaan Yogyakarta. Istoria, 11(1), 87-102.

Franco, Z. \& Zimbardo, P. (2007). The banality of heroism. Greater Good, 3, 3035 .

Graaf, H. J. D. \& Pigeaud, TH. (2003). Kerajaan Islam pertama di Jawa tinjauan sejarah politik Abad XV dan XVI. Jakarta: Pustaka Utama Grafiti (Terjemahan Utama Grafiti dan KITLV).

Gunawan, R., Bandarsyah, D., \& Fauzi W.I. (2019). Chaos, moral decadence, and betrayal (satire in "di tepi kali bekasi" novel by Pramoedya Ananta Toer). Litera, 18(1), 71-91.

Kumaidi. (2017). Konteks sejarah maritim Indonesia dalam novel Arus Balik kaya Pramoedya Ananta Toer kajian new historism. EDU-KATA, 4(2), 195-204.

Kurniawan, R. (2017). Antara sejarah dan sastra: novel sejarah sebagai bahan ajar pembelajaran sejarah. Sejarah dan Budaya, 11(1), 55-70. DOI: http://dx.doi.org/10.17977/um020v11i12017p055.

Nugraha, A.E., Wardhani, N.E., \& Rakhmawati, A. (2019). Karakter tokoh utama novel Kinanti karya Margareth Widhy Pertiwi. Indonesian Language Education and Literature, 4(2), 171-185. DOI: http://dx.doi.org/10.24235/ileal.v4i2.2602.

Poesponegoro, M. D. \& Notosusanto, N. (1984). Sejarah nasional Indonesia III. Jakarta: Balai Pustaka.

Primasari, W. (2014). Heroisme Amerika dalam film. Makna, 4(2), 35-53. 


\section{Indonesian Language Education and Literature e-ISSN: 2502-2261 \\ http://www.syekhnurjati.ac.id/jurnal/index.php/jeill/ \\ Vol. 5, No. 1, Desember 2019, 33 - 46}

Rivaie, W. (2011). Asimilasi nilai kekeluargaan lintas etnik. Visi, 6(1), 93-105. DOI: https://doi.org/10.21009/JIV.0601.10.

Sudikan, S.Y. \& Tjahjono, T. (2018). Covert Insubordination in Arus Balik Novel of Pramoedya Ananta Toer: Perspective of Social Movements. Budapest International Research and Critics Institute-Journal, 1(4), 232-244.

Sulistiyono, S.T. (2018). Nasionalisme, negara-bangsa, dan integrasi nasional Indonesia: masih perlukah? Citra Lekha, 3(1), 3-12.

Wahyudi, D.Y. (2013). Kerajaan Majapahit: dinamika dalam sejarah Nusantara. Jurnal Sejarah dan Budaya, 7(1), 88-95. 